\title{
Does Immigration Boost Per Capita Income?*
}

\author{
Gabriel J. Felbermayr $†$ Sanne Hiller $\ddagger$ and Davide Sala ${ }^{\S}$
}

October, 2008

\begin{abstract}
Using a cross-section of countries, we adapt Frankel and Romer's (1999) IV strategy to international labor mobility. Controlling for institutional quality, trade, and financial openness, we establish a robust and non-negative causal effect of immigration on real percapita income.
\end{abstract}

Keywords: Gravity model, international trade, international migration, cross-country income regression.

JEL-Codes: F22, F12

*We thank Wilhelm Kohler and the participants at the Workshop "Migration and Labor Market Integration" at Tübingen University for comments. The project was supported by grant no. 10.06.1.111 of the Thyssen Foundation. The Development Research Centre on Migration, Globalization and Poverty, at University of Sussex has kindly provided us with the data. All remaining errors are ours. A replication archive is available on www.asb.dk/staff/dsala

${ }^{\dagger}$ gabriel.felbermayr@uni-hohenheim.de; Department of Economics, University of Stuttgart-Hohenheim, 70593 Stuttgart, Germany.

${ }^{\ddagger}$ sanh@asb.dk; Department of Economics, Aarhus School of Business, University of Aarhus, Hermodsvej 22, 8230 Aabyhøj, Denmark

${ }^{\S}$ Corresponding author: dsala@asb.dk; Department of Economics, Aarhus School of Business, University of Aarhus, Hermodsvej 22, 8230 Aabyh $ø$ j, Denmark. 


\section{Motivation}

Advocates of liberal policies argue that immigration raises the income of native factor owners (Borjas, 1994). For this immigration surplus to materialize, the aggregate production function must display complementarity between inputs and the factor-content of the immigrant inflow must have a different composition than the pre-existing stock of natives. ${ }^{1}$ In contrast, per capita income- including immigrants- does not necessarily go up. If immigrants are on average poorer than natives, it trivially falls. ${ }^{2}$ Besides being of intrinsic interest, the per capita income effect determines whether the winners of immigration can potentially compensate the losers without excluding the immigrants from the redistribution scheme.

In the long-run, if immigrants assimilate perfectly (i.e. become indistinguishable from natives) and the capital stock adjusts, per capita income reverts to the initial level. However, even in the long-run, migrants may have different propensities to accumulate financial and human capital than natives, which affects per capita income. Moreover, Ottaviano and Peri (2006) argue that the diversity-enhancing effect of immigration increases the value of aggregate output. Still, there may be an opposite effect, if immigration exacerbates ethnic tensions. These ambiguities call for an empirical assessment, the first one - to our best knowledge - on a broad number of countries. ${ }^{3}$

We deal with the endogeneity of immigration to per capita income constructing the geographical component of migration from cross-country data on bilateral migrant stocks and using it as an instrument - akin to Frankel and Romer's (1999, henceforth F\&R) for trade openness. Based on non-weak instruments, our analysis establishes a robust, non-negative effect of immigration on per capita income.

\footnotetext{
${ }^{1}$ Other conditions, such as the absence of distortions must hold too.

${ }^{2}$ Total GDP always increases if immigrants find productive employment.

${ }^{3}$ Buch and Toubal (2008) account for labor market openness in their study of German states.
} 


\section{Empirical strategy}

Income regression. Following a well established literature, we estimate the following crosscountry income regression:

$$
\ln y_{i}=\alpha+\beta_{M} \ln M_{i}+\beta_{T} T_{i}+\beta_{F} F_{i}+\gamma^{\prime} \boldsymbol{\Gamma}_{\mathbf{i}}+\iota I_{i}+u_{i},
$$

where $i$ is the country index, $y_{i}$ is per capita GDP (constant dollar PPP, in 2000) and $M_{i}$ the stock of immigrants. The vector $\boldsymbol{\Gamma}_{i}$ contains population, land surface, a continuous measure of landlockedness - to capture domestic market size - and the malaria index - to control for geography (Rodrik et al., 2004). ${ }^{4} I_{i}$ proxies institutional quality (Glaeser et. al., 2004).

Our focus is on $\beta_{M}$. Since we include population (native and foreign-born), $\beta_{M}$ does not measure the pure size effect of immigration but rather its compositional effect, namely the one of an increase in the immigrant share.

A country's attitude towards migration is likely shaped by its history and culture. Unable to use fixed effects in a cross-section, we account for unobserved heterogeneity by inclusion of $T_{i}$ - the ratio of exports and imports over GDP - and $F_{i}$ - an indicator of financial market integration. We presume that a liberal attitude towards labour flows comes along with a high degree of integration on goods and financial markets.

Instrumental Variables. $M_{i}, T_{i}$, are potentially endogenous. Following F\&R, we exploit geographical variation to instrument $T_{i}$. We extend this strategy to $M_{i}$, using a 226x226 matrix of international bilateral migrant stocks for the year 2000. Migrants are defined as "foreign-born", so that our measure is unaffected by national naturalization policies. Let $M_{i j}$ denote the number of individuals born in country $j$ and residing in $i$. Then, $M_{i}=\sum_{j \in J} M_{i j}$ is the total immigrant stock.

Let

$$
E\left(X_{i j} \mid \mathbf{G}_{\mathbf{i j}}, A D J_{i j}\right)=\exp \left[\mathbf{G}_{i j} \boldsymbol{\gamma}_{X}+A D J_{i j} \lambda_{X}+\left(\mathbf{G}_{i j} A D J_{i j}\right) \boldsymbol{\delta}_{X}\right]
$$

\footnotetext{
${ }^{4}$ The index of landlockedness is the share of land borders in total border length. Compare Sachs (2003).
} 
with $X \in\{M, T\} . \mathbf{G}_{i j}$ is a vector containing geographical variables (landlockedness, ln population in 1960, ln area for each $i$ and $j$ and ln bilateral distance) and $A D J_{i j}$ an adjacency dummy. ${ }^{5}$ We use Poisson Pseudo Maximum Likelihood (PPML) to estimate (2) for the year 2000 (see Santos and Tenyreyro (2006)). Our instruments are computed as $\hat{X}_{i}=\sum_{j} \hat{X}_{i j}$, $\hat{X}_{i j}=\mathbf{G}_{i j} \hat{\gamma}_{X}+A D J_{i j} \hat{\lambda}_{X}+\left(\mathbf{G}_{i j} A D J_{i j}\right) \hat{\boldsymbol{\delta}}_{X}$ is the in-sample linear prediction. ${ }^{6}$

Three remarks are in order. First, PPML estimation yields stronger instruments compared to OLS, since it accounts for cases with $X_{i j}=0$, representing a non-negligable share of countrypairs $\left(6(3) \%\right.$ of $M_{i j}\left(T_{i j}\right)$ in the respective sample).

Second, $\hat{X}_{i}$ is a generated measure of multilateral remoteness determined exclusively by geography. Hence, no concerns about consistency of (2) as a gravity equation arise.

Third, $\hat{M}_{i}$ and $\hat{T}_{i}$ prove to be collinear in our regression analysis, leading to weak-instruments when used simultaneously. On the presumption a country's remoteness affects economic and psychological cost of migration, we shall use $\tilde{M}_{i}=\frac{1}{N-1} \sum_{w} D_{w i}$ as an alternative instrument for $M_{i}$ ( $N$ is the number of countries and $D_{w i}$ is bilateral distance).

$F_{i}$ and $I_{i}$ may well be endogenous, but simultaneous instrumentation of many endogenous regressors exacerbates the concern for weak instruments. Since good bilateral data for financial flows are rare, we abstain from instrumenting $F_{i}$ like $X_{i}$, but rather proxy $F_{i}$ by the (ln) distance to the closest major financial center (Rose and Spiegel, 2008). $I_{i}$ is constitutional review (La Porta et. al., 2004). Compared to alternative common measures (e.g. expropriation risk or government effectiveness), it reflects permanent constraints on the executive authority, rather than election outcomes or temporary policies (Glaeser et al., 2004). By definition, endogeneity concerns are attenuated.

\footnotetext{
${ }^{5}$ The specification is borrowed from F\&R. Lewer and van den Berg (2008) show that bilateral migration flows are accurately predicted by geographical variables (along with income and population).

${ }^{6}$ Using only in-sample predictions increases precision, compare Noguer (2005).
} 


\section{Results}

The elasticity of $y$ with respect to the migrant stock is (significantly) positive throughout all specification in Table 1. Most importantly, weakness of instruments is of no concern (see the minimum eigenvalue statistics - Stock and Motohiro (2002)).

Effect of Immigration. (2) and (3) provide IV estimates based on $\hat{M}$ and $\tilde{M}$, respectively. The different performance in (2) relative to (3) is ascribed to the correlation of 0.52 between $\hat{M}$ and $T$ (and, therefore with the residual), whereas $\tilde{M}$ is free of this problem. Overall, OLS underestimates $\beta_{M}$. Several factors weigh upon this discrepancy. On the one hand, measurement error in the migrant stock causes attenuation bias in OLS. On the other hand, unobserved heterogeneity $(T, F)$, would cause overestimation of OLS. Finally, the direction of the simultaneity bias(reverse causality of $M$ and $y$ ) is ambiguous.

Interestingly, throughout first stage regressions, $\tilde{M}$ is negatively correlated with immigration, but positively associated with trade openness.

Trade Openness. In (5), we add trade openess. To avoid the multicollinearity between $\hat{T}$ and $\hat{M}$ when jointly used, we instrument $M$ with $\tilde{M}$ and $T$ with $\hat{T} \cdot{ }^{7}$ The absence of such multicollinearity is essential to disentangle the effect of labour from goods market integration.

Financial Openness. (6) and (7) additionally control for financial openness. This undoes the statistical significance of the immigration effect, but preserves its positive sign. A similar effect is produced by the direct inclusion among the regressors of the great circle distance, strongly correlated with Rose and Spiegel's indicator $(\rho=0.6059)$. Interestingly, the positive effect of trade openness remains.

Geography and Institutions. (1) to (7) draw on the largest possible sample, while (8) to (11) use a smaller sample for which institutional quality data is available. These 63 countries

\footnotetext{
${ }^{7}$ An F-test on the first stage (regressing $T$ on $\hat{T}$ and $\hat{M}$ ), reveals both instruments are jointly but not individually significant. In this case, weakness of instruments cannot be rejected. Multicollinearity persists even if (2) is not identically specified for $M_{i j}$ and $T_{i j}$.
} 
tend to be richer, and presumably, have better data quality. Specifications (8) and (9) control for a direct effect of geography - see Sachs (2003) - extending (6) and (7) with the inclusion of a malaria index. Adding institutional controls (coefficients not displayed) in (10) and (11) leaves the coefficients on immigration, trade and financial integration fairly unchanged. The IV and OLS estimates are considerably close. Finally, the inclusion of ethnic fragmentation (Alesina et al., 2003) leaves estimates qualitatively unchanged (not reported).

\section{Summary}

Using geography-based instruments and controlling for the sheer population size effect, we find robust evidence for immigration to be non-negatively causally related to per capita income. Hence, immigration gives rise to a gain that can - in principle - be used to make the native population better off without excluding the immigrants from the redistribution scheme.

Our preferred specification - columns (10) and (11) in Table 1 - imply that a $10 \%$ increase in the migrant stock leads to a per capita income gain of $2.2 \%$. We also find that trade and financial integration positively affect per capita income. 


\section{A Data Sources}

- Population, GDP per capita (2000 PPP USD) $\left(y_{i}\right)$ : World Development Indicators 2007.

- Bilateral migration stocks $\left(M_{i j}\right)$ : World Bank, Development Research Centre on Migration, Globalisation and Poverty. ${ }^{8}$

- Bilateral trade data $\left(T_{i j}=\left(X_{i j}+X_{j i}\right) / Y_{i}\right)$ : Direction of Trade Statistics, IMF, Sept. 2006 CD-ROM.

- Trade openness $\left(T_{i}\right)$ : Penn World Tables 6.2.

- Adjacency $\left(A D J_{i j}\right)$, Area, bilateral distance: CEPII, Paris. ${ }^{9}$

- Financial Openness $\left(F_{i}\right)$ proxy: negative of Rose (2008).

- Constitutional Review $\left(I_{i}\right)$ : La Porta et al. (2004).

- Landlockedness: CIA World Factbook 2008.

- Malaria Index: Rodrick et al. (2004).

\section{References}

[1] Alesina, A., Devleeschauwer, A., Easterly, W., Kurlat, S. and Wacziarg, R. (2003). Fractionalization. Journal of Economic Growth 8(2): 155-194.

[2] Borjas, G.J. (1994). The Economics of Immigration. Journal of Economic Literature 32(4): 1667-1717.

[3] Buch, C.M., Toubal, F. (2008). Openness and Growth: The Long Shadow of the Berlin Wall. Journal of Macroeconomics, doi: 10.1016/j.jmacro.2008.07.004.

[4] Frankel, J.A., and Romer, D. (1999). Does Trade Cause Growth? American Economic Review 89(3): 379-399.

[5] Glaeser, E. L., La Porta, R. F. L., and Shleifer, A. (2004). Do Institutions Cause Growth?. Journal of Economic Growth 9(4): 271-303.

[6] La Porta, Rafael F. L., Lopez-de-Silanes, F., Pop-Eleches, C., Shleifer, A. (2004). Judicial Checks and Balances. Journal of Political Economy, 112(2): 445 - 470.

[7] Lewer, J.J., and Van den Berg, H. (2008). A gravity model of immigration. Economics Letters 99(1): 164-167.

[8] Noguer, M.,Siscart, M. (2005). Trade raises income: a precise and robust result. Journal of International Economics vol. 65(2): 447-460.

[9] Ottaviano, G. and G. Peri (2006). Rethinking the Effects of Immigration on Wages. NBER Working Paper (12496).

\footnotetext{
${ }^{8}$ http : //www.migrationdrc.org/research/typesofmigration/global_migrant_origin_database.html

${ }^{9}$ www.cepii.fr/anglaisgraph/bdd/distances.htm
} 
[10] Rodrik, D., Subramanian A., and Trebbi F. (2004). Institutions rule: the primacy of institutions over geography and integration in economic development. Journal of Economic Growth 9(2): 271-293.

[11] Rose, A. K., and Spiegel, M. M. (2008). International Financial Remotness and Macroeconomic Volatility. Mimeo, University of California Berkeley.

[12] Sachs, J. D. (2003) Institutions don't Rule: Direct Effects of Geography on per capita Income, NBER WP 9490.

[13] Santos Silva, J.M.C. and Tenreyro, S. (2006). The log of gravity. Review of Economics and Statistics 88 (4): 641-658.

[14] Stock, J., Motohiro, Y. (2002). Testing for Weak Instruments in Linear IV Regression. NBER Technical WP 0284. 
Table 1. Per capita income and immigration

(A) Second-stage regressions

Large sample ( $\mathrm{N}=162)$

\begin{tabular}{lll}
\hline$(1)$ & $(2)$ & $(3)$ \\
\hline OLS & IV & IV \\
$0.261^{\star \star *}$ & $0.810^{\star \star *}$ & $0.535^{\star \star \star}$ \\
$(0.0462)$ & $(0.153)$ & $(0.138)$
\end{tabular}

(4)

OLS

0.240 ***

$(0.228)$ $0.0191^{\star \star \star}$

$(0.00191) \quad(0.00724)$

Finance (F)

Market Size

Geography

Institution

Adj R2 / Wald Chi

MES

yes

yes

yes

yes

yes

0.387

$\begin{array}{ll}66.20 & 79.10 \\ 27.86 & 18.03\end{array}$

$27.86 \quad 18.03$

Variable instrumented:

$\hat{M}$

$\hat{T}$

Finance (F)

F-stat. on Excl. Instruments

0.556

28.82

0.531
16.49

16.49

0.549

15.94

0.375

3,996

68.09

68.09
5,506

\begin{tabular}{ll}
$(6)$ & $(7)$ \\
\hline OLS & IV
\end{tabular}

$0.210^{* * *}$

$(0.133)$

$0.00358^{\star \star *} \quad 0.0151^{\star *}$

$(0.00125) \quad(0.00656)$

$0.723^{\star \star \star} \quad 0.582^{\star \star *}$

(0.0965) (0.159)

yes

yes

$0.542 \quad 161.7$

6,351

(B) First-stage regressions

Market Size Controls: In Area, In Population 1960, Landlockedness. Geography Controls: Malaria Index. Institutional Controls: Constitutional Review. All first stage regressions include all exogeneous regressors (not shown).

Small sample $(\mathrm{N}=63)$

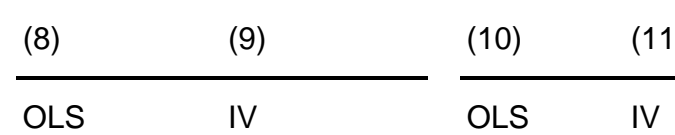

$0.231^{\star \star \star} \quad 0.226^{\star \star} \quad 0.232^{\star \star *} \quad 0.221^{\star *}$

$\begin{array}{llll}(0.0539) & (0.0897) \quad(0.0531) & (0.0875)\end{array}$

$\begin{array}{llll}0.00109 & 0.00457 & 0.00104 & 0.00456\end{array}$

$\begin{array}{llll}(0.00125) & (0.00301) & (0.00126) & (0.00295)\end{array}$

$0.426^{\star \star \star} \quad 0.415^{\star \star \star} \quad 0.431^{\star \star \star} \quad 0.420^{\star \star \star}$

$\begin{array}{llll}(0.0948) & (0.0981) \quad(0.1000) & (0.101)\end{array}$

yes yes yes yes

yes yes yes yes

$0.774 \quad 475.7 \quad 0.773 \quad 488.2$

\begin{tabular}{rr}
4,066 & 6,921 \\
\hline
\end{tabular}

" 